\title{
Impact of Physical Ergonomic Factors on Employee Productivity: Special Reference to in Apparel Industry of Gampaha District
}

\author{
D.A.S.M. Silva ${ }^{1}$ \& D.M.T.D. Dissanayake ${ }^{2}$ \\ ${ }^{1,2}$ Department of Business Management \\ Faculty of Business Studies \& Finance \\ Wayamba University of Sri Lanka \\ Kuliyapitiya \\ SRI LANKA \\ Sanjukasilva21@gmail.com ${ }^{1}$, tanyad@wyb.ac.lk ${ }^{2}$
}

\begin{abstract}
A well-designed work environment is a prerequisite for any organizational employee retention and quality maintenance. Businesses do not operate in a vacuum but rather in a dynamic environment that has a direct influence on how they operate and whether they will achieve their objectives. In today's context, apparel industries pay a greater attention toward physical ergonomic factors Ergonomics is designed to ensure that the work situation is in line with the worker's activities. Thus, the present research was conducted to determine the impact of physical ergonomic factors on employee productivity in apparel industry of Gampaha district. The variables included in the framework were internal Environmental factors, Working Equipment and workplace design. The primary data was gathered by distributing 323 questionnaires to employees who work in apparel manufacturing companies located in Gampaha district. The findings determined that, all three factors: internal environmental factors, working equipment and workplace design, were significant variables and has a positive impact on employee productivity of apparel manufacturing industry. The research paper provides apparel industry on how knowledge about the physical ergonomics factors influencing employee productivity.
\end{abstract}

Keywords: Physical Ergonomic Factors, Employee Productivity, Apparel Manufacturing Industry

\section{INTRODUCTION}

Nowadays, ergonomics is one of the least recognized facts in country's industrial and services community. It lays the groundwork for many policies and programs in management and engineering. The purpose of applying ergonomic data is to reach appropriate and logical relation between employees and environment, machine, job as well as organization.

Having an appropriate physical work environment condition, it helps in reducing the amount of absenteeism and consequently can expand the employees' productivity which will prompt the expanding number of profitability at the working environment. Ergonomics is a science, 
concerned with the fit 'between people and their work. It puts people first, taking account of their capabilities and limitations. Ergonomics aims to make sure that tasks, equipment, information and the environment fit each worker (Britain, 2014)

A conducive physical work environment condition, it helps in reducing the quantity of absenteeism and consequently can expand the employees' productivity which will prompt the expanding number of profitability at the working environment. Thus, it is so critical to discover what factors of work environment conditions cause for the employees' productivity. In the world, there are international organizations who debate the rights of employee.

Most people spend fifty percent of their lives within indoor environments, which greatly influence their mental status, actions, abilities and performance (Dorgan, 1994). Better outcomes and increased productivity are assumed to be the result of better workplace environment. Better physical environment of office will boost the employees and ultimately improve their productivity.

Employee productivity, also called workplace productivity, is an assessment of an employee's or a group of employees' efficiencies. It is evaluated by looking at the total workforce or employee output in a given time. In most cases, the productivity of an individual will be assessed in comparison to the average output of other employees doing similar work. When employees are productive, it can increase the company's revenue, and in turn, a company may choose to offer incentives to its employees. Failing to reward a productive staff can demotivate the whole team.

\subsection{Problem Statement}

It is believed that employee efficiency and increased productivity are the products of a stronger workplace environment. Employees should be supported with comfortable working atmosphere to do their level best. Lack of comfortable working conditions Employees are suffering from job satisfaction. This issue affects not only employee performance, but also employee absenteeism and turnover work dissatisfaction and employee health and safety related issues directly or indirectly. A well-designed work environment, as well as maintaining the organization's profitability, is important for the prevention of diseases related to poor working conditions. Information technology is being updated and the creation of new forms of organizations.

One of the most important factors in employee performance is to achieve goals. Successful employees always tend to achieve organizational objectives. There is no doubt about the fact that the human asset is the key intangible asset for any organization. In today's dynamic and continuously changing business world, it is the human assets and not the fixed or tangible assets that differentiate an organization from its competitors. Noble (2009) states that more attention should be paid in identifying 
and dealing with working environment because when employee have negative perception to their environment they sometimes suffer from chronic stress. Literature on the study of multiple offices and office buildings indicate that factors such as dissatisfaction, cluttered workplaces and the physical environment are playing a major role in the loss of employees' productivity (Carnevale 1992, Clements-Croome 1997).

According to the McCoy \& Evans (2005), if employees dissatisfy with their working environment and once the employees become stressors at the workplace, the employees tend to do their work very slowly. This will directly affect for the employee's performance and as well as for the overall productivity of the organization. The problem which reveal by McCoy \& Evans (2005) also can be observed in the apparel industry of Sri Lanka. However, there is no enough research in this area in Sri Lanka. Researcher's effort was to investigate the impact of physical ergonomic factors on employee productivity in apparel industry of Gampaha District. Therefore, this research empowers the researchers to recognize physical ergonomic factors on employee productivity in apparel industry of Gampaha District.

\subsection{Research Objectives}

The objectives for the present study as follow,

To analyze the impact of Internal Environmental Factors towards employee Productivity in Apparel Industry of Gampaha district
To analyze the impact of Working Equipment towards employee Productivity in Apparel Industry of Gampaha district

To analyze the impact of Workplace Design towards employee Productivity in Apparel Industry of Gampaha district

\subsection{Contribution of the paper}

The study helps to understand the impact of physical ergonomic factors on employee productivity in apparel industry of Sri Lanka and, it helps to find out possible solutions for the impact of physical ergonomic factors which increase the employee productivity. Therefore, the company managements of apparel industry can focus on the research findings and it will help the managements to be more success. Also, management in the apparel industry can use this study to understand a better development and the Human Resource aspect from the findings of the study.

\subsection{Literature Review}

In the study of Brill et al (1985), he reveals that a physical work environment can result a person to fit or misfit to the environment of the workplace and it is also known as an ergonomic workplace. There are some factors of physical work environment which help employees to perform their job more effectively and which leads to enhance their job satisfaction, such as lightings, the floor configuration, office layout and also the furniture layout.

According to the Vischer (2007), physical work environment is one of 
the most important factors which influences on work performance. Evidence accumulated that the physical work environment in which people work affects both job performance and job satisfaction. And also, he reveals that employees affect by the environment of the place they are working and by having a good environment, the employees could apply their energy and their full attention to perform work.

McCoy \& Evans (2005) explained that if employees dissatisfy with their working environment and once the employees become stressors at the workplace, the employees tend to do their work very slowly. This will directly affect for the employees performance and as well as for the overall productivity of the organization.

According to Mohr, (1996) to achieve high levels of employee productivity, organizations must ensure that the physical environment is conducive to organizational needs facilitating interaction and privacy, formality and informality, functionality and crossdisciplinarily. Consequently, the physical environment is a tool that can be leveraged both to improve business results and employee well-being

In the study of Huang, Robertson and Chang (2004), he ensuring adequate facilities are provided to employees is critical to generating greater employee commitment and productivity. The provision of inadequate equipment and adverse working conditions has been shown to affect employee commitment and intention to stay with the organization.
Ismail et al. (2010) opine that the conditions of physical workplace environment influence the employees' functions and it will determine the well-being of organizations. They add that the physical work environment includes the internal and external office layout, temperature, comfort zone and also the work setting or arrangement.

Niemela et al. (2002) found out that there is decrement in work performance when temperatures are high, and low temperature has relation to performance of manual tasks.

Tamessek (2009) analyzed the extent to which employees perceive their workplace environment as fulfilling their intrinsic, extrinsic, and social needs and their need to stay in the organization. He also analyzed the impact of perception of workplace environments on employee commitment and turnover in the organization, he concluded that if the employees are provided with enabling workplace environmental support, they will be highly satisfied and show high level of commitment towards their organization and hence low turnover rate.

A research by Roelofsen (2002) indicates that improving the working environment reduces complains and absenteeism while increasing productivity. Better physical workplace environment will boost the employee and ultimately their performance. A study done by Chevalier (2004) revealed that when environmental supports are sound, employees are better equipped to do what is expected of them. 
Findings by Ajala (2012) indicated that workplace environmental elements such as sufficient light, absence of noise, proper ventilation and layout arrangement substantially increase employees' 13 productivity. Hameed and Amjad (2009) in a survey of 31 bank branches showed that comfortable and ergonomic office design motivates the employees and increased their performance substantially.

\section{METHODS}

There are approximately 2000 employees available in the selected two garment manufacturing organization in the Gampaha district. According to Krejcie \& Morgan table (1970), 323 employees were selected based on purposive sampling method. Data were collected through primary sources using the questionnaire method and questions were arranged according to five-point Likert scale to gain the responses. $100 \%$ valid responses were gained. The conceptual model of the study can be presented as follows.

\subsection{Conceptual Framework}

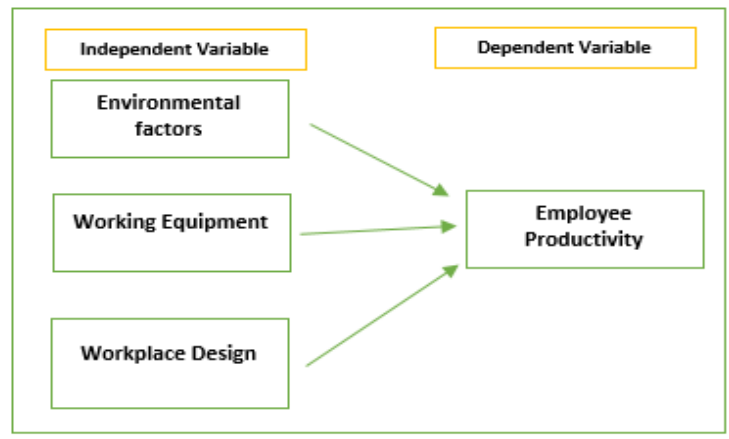

Figure 1. Conceptual Framework

\subsection{Development of Hypothesis}

Based on the literature, the researcher has developed three hypotheses as follows.

$\mathrm{H}_{1}$ : There is a significant effect of Environmental factors on employee productivity in Apparel industry of Sri Lanka.

$\mathrm{H}_{2}$ : There is a significant effect of Working Equipment on employee productivity in Apparel industry of Sri Lanka.

$\mathrm{H}_{3}$ : There is a significant effect of Workplace Design on employee productivity in Apparel industry of Sri Lanka.

\section{RESULTS}

To measure the reliability and validity in this study the researcher uses "Cronbach's Alpha" separately for "the drivers of impacted to the Employee Productivity such as Environmental Factors, Working Equipment and Workplace Design as well as dependent drivers of the Employee Productivity of the Employees in Apparel Industry of Sri Lanka".

Reliability of questionnaire has been measured by using Cronbach's' alpha and to identify In order to find out the relationship between Physical ergonomic factors and Employee productivity, correlation coefficient is used.

The Cronbach's' alpha value for the observed independent variables are 0.755 for internal environmental 
Factors, 0.755 for Working Equipment ,0. 734 for Workplace Design, where all the values are in the satisfactory level of reliability.

Table 1. Descriptive Statistics

\begin{tabular}{|c|c|c|c|c|}
\hline \multicolumn{5}{|c|}{ Descriptive Statistics } \\
\hline & $\begin{array}{l}\text { Interna } \\
1 \\
\text { enviro } \\
\text { nment } \\
\text { al } \\
\text { Factor } \\
\mathrm{s}\end{array}$ & $\begin{array}{l}\text { Work } \\
\text { ing } \\
\text { Equip } \\
\text { ment }\end{array}$ & $\begin{array}{l}\text { Workp } \\
\text { lace } \\
\text { Design }\end{array}$ & $\begin{array}{l}\text { Empl } \\
\text { oyee } \\
\text { Produ } \\
\text { ctivity }\end{array}$ \\
\hline $\begin{array}{l}\text { Mea } \\
\mathrm{n}\end{array}$ & 2.3100 & $\begin{array}{l}2.313 \\
1\end{array}$ & 2.2874 & $\begin{array}{l}2.166 \\
9\end{array}$ \\
\hline $\mathrm{N}$ & 321 & 321 & 321 & 321 \\
\hline $\begin{array}{l}\text { Std. } \\
\text { Devi } \\
\text { atio } \\
\mathrm{n}\end{array}$ & .42757 & $\begin{array}{l}.5245 \\
1\end{array}$ & .52679 & $\begin{array}{l}.5075 \\
3\end{array}$ \\
\hline $\begin{array}{l}\text { Mini } \\
\mathrm{mu} \\
\mathrm{m}\end{array}$ & 1.00 & 1.00 & 1.00 & 1.00 \\
\hline $\begin{array}{l}\text { Max } \\
\text { imu } \\
m\end{array}$ & 5.00 & 5.00 & 5.00 & 5.00 \\
\hline $\begin{array}{l}\text { Vari } \\
\text { ance }\end{array}$ & 183 & .275 & .278 & .258 \\
\hline $\begin{array}{l}\text { Ske } \\
\text { wne } \\
\text { ss }\end{array}$ & 1.459 & .831 & .963 & 1.097 \\
\hline
\end{tabular}

As per table number 1 descriptive were analyzed. This result leads the study with the non-parametric for individual driver analysis. In this study data are categorical and not normally distributed. Therefore, examination should be done with $\mathrm{Chi}$ - Square test results, (Gujarati and Porter 2009).

Chi - Square test were used with $05.00 \%$ significance level for the study. The individual drivers such as Environmental Factors (Chi-Square Statistic - 337.255) (Sig. - 0.000), Working Equipment (Chi-Square Statistic - 412.801) ( Sig. - 0.000), Workplace Design (Chi-Square Statistic - 487.380) (Asymp. Sig. 0.000) have an effect on Employee Productivity at the Apparel Industry of Sri Lanka at $05.00 \%$ level of significance.

To find the individual drivers' sign of the effect which is positive or negative to the Employee Productivity; researcher has used correlation analysis with Spearman Correlation Coefficient due to the data categorical and not normally distributed.

According to the Spearman rank-order correlation analysis the drivers of the Independent factors such as the Internal environmental Factors are strong positively (Correlation Coefficient -0.756$)(\mathrm{P})-0.000)<$ 0.05 correlated with on Employee Productivity. Working Equipment are weak positively (Correlation Coefficient - 0.510) $(\mathrm{P})-0.000)<$ 0.05 correlated with on Employee. And Workplace Design are weak positively (Correlation Coefficient $0.569)(\mathrm{P})-0.000)<0.05$ correlated with on Employee Productivity at the Apparel Industry of Sri Lanka.

As per the above result most impacted variable is Environmental Factors on the Employee Productivity due to it has the highest Correlation Coefficient: A Case of the Apparel Industry of Sri Lanka at $05.00 \%$ level of significance. 
Table 2. Model Summary

\begin{tabular}{|c|c|c|c|c|c|}
\hline \multicolumn{6}{|c|}{\begin{tabular}{|l} 
Model Summary $^{b}$ \\
\end{tabular}} \\
\hline \multirow[b]{2}{*}{ Model } & \multicolumn{2}{|c|}{$\begin{array}{l}\text { Unstan } \\
\text { dardize } \\
\text { d } \\
\text { Coeffic } \\
\text { ients }\end{array}$} & $\begin{array}{l}\text { Stan } \\
\text { dardi } \\
\text { zed } \\
\text { Coef } \\
\text { ficie } \\
\text { nts }\end{array}$ & & \\
\hline & $\mathrm{B}$ & $\begin{array}{l}\mathrm{St} \\
\mathrm{d} . \\
\mathrm{Er} \\
\text { ro } \\
\mathrm{r}\end{array}$ & Beta & $\mathrm{T}$ & $\begin{array}{l}\mathrm{S} \\
\mathrm{i} \\
\mathrm{g} \\
.\end{array}$ \\
\hline $\begin{array}{l}\text { (Cons } \\
\tan t)\end{array}$ & $\begin{array}{r}.0 \\
27\end{array}$ & $\begin{array}{r}.1 \\
07\end{array}$ & & $\begin{array}{l}.2 \\
4 \\
7\end{array}$ & $\begin{array}{l}\cdot \\
8 \\
0 \\
5\end{array}$ \\
\hline $\begin{array}{l}\text { Envir } \\
\text { onme } \\
\text { ntal } \\
\text { Facto } \\
\text { rs }\end{array}$ & $\begin{array}{r}.3 \\
89\end{array}$ & $\begin{array}{r}.0 \\
59\end{array}$ & .328 & $\begin{array}{l}6 . \\
6 \\
4 \\
8\end{array}$ & $\begin{array}{l}\dot{0} \\
0 \\
0\end{array}$ \\
\hline $\begin{array}{l}\text { Work } \\
\text { ing } \\
\text { Equip } \\
\text { ment } \\
\end{array}$ & $\begin{array}{r}.1 \\
95\end{array}$ & $\begin{array}{r}.0 \\
47\end{array}$ & .201 & $\begin{array}{r}4 . \\
1 \\
1 \\
9 \\
\end{array}$ & $\begin{array}{l}. \\
0 \\
0 \\
0\end{array}$ \\
\hline \begin{tabular}{|l|} 
Work \\
place \\
Desig \\
$\mathrm{n}$
\end{tabular} & $\begin{array}{r}.3 \\
46\end{array}$ & $\begin{array}{r}.0 \\
46\end{array}$ & .359 & $\begin{array}{r}7 . \\
5 \\
3 \\
6\end{array}$ & $\begin{array}{l}. \\
0 \\
0 \\
0\end{array}$ \\
\hline $\begin{array}{l}\text { a. Depeno } \\
\text { Productiv }\end{array}$ & M & arta & $\mathrm{e}: \mathrm{El}$ & & \\
\hline
\end{tabular}

According to the table of model summary, the selected independent variables are explained the total variation of the Employee Productivity; A Case of the Apparel Industry of Sri Lanka by $57.10 \%$ and which results overall significance due to P-value of ANOVA table (0.000) and $(\mathrm{F}$ value -143.081$)$ is less than 0.05 . In this analysis, $\mathrm{R} 2$ cannot be used to measure the goodness of fit due to multiple linear regression model.

Table 3. Regression Coefficients

\begin{tabular}{|c|c|c|c|c|}
\hline $\begin{array}{l}\text { Mo } \\
\text { del }\end{array}$ & $\mathrm{R}$ & $\begin{array}{l}\mathrm{R} \\
\text { Squ } \\
\text { are }\end{array}$ & $\begin{array}{l}\text { Adjus } \\
\text { ted R } \\
\text { Squar } \\
\text { e }\end{array}$ & $\begin{array}{l}\text { Std. } \\
\text { Error } \\
\text { of the } \\
\text { Estim } \\
\text { ate }\end{array}$ \\
\hline 1 & $\begin{array}{l}.75 \\
8^{a} \\
\end{array}$ & .575 & .571 & $\begin{array}{l}.3323 \\
5 \\
\end{array}$ \\
\hline $\begin{array}{l}\text { a. } \\
\text { Wo } \\
\text { Equ } \\
\text { Fac }\end{array}$ & \multicolumn{4}{|c|}{$\begin{array}{l}\text { Predictors: } \\
\text { place Design, } \\
\text { ment, Internal Environmental } \\
\text { rs }\end{array}$} \\
\hline $\begin{array}{l}\text { b. I } \\
\text { Pro }\end{array}$ & & & ble & loyee \\
\hline
\end{tabular}

Regression coefficients represent the mean change in the response variable for one unit of change in the independent or predictor variable while holding other predictors in the model are constant. According to the regression results, all the independent variables have a significant impact on Employee Productivity. The most impacted variable is Internal Environmental Factors due to it has the highest $\mathrm{B}$ value (Regression Coefficient) on Employee Productivity:

There is a significant impact of all the Independent variables on Employee Productivity in Apparel Industry of Gampaha District. According to the regression analysis, $\mathrm{p}$ value of all the Independent factors was 0.000 (less than 0.05), hence the null hypothesis was rejected. Alternative hypothesis was accepted. It means that, the changes in Independent variables have a significant impact on Employee 
Productivity in Apparel Industry of Gampaha District.

So according to above Results, All the Hypothesis formulated in this Study were Accepted.

\section{DISCUSSION}

According to the analysis, it was found that there is a significant Impact of Physical Ergonomic Factors on Employee Productivity in Apparel Industry of Gampaha District.

The normality test was done with the values of Skewness. Here the data of the selected sample were not completely normally distributed, however those were distributed in a sufficient level to go for further analysis techniques.

The first and main objective of the study was to investigate the Impact of Physical Ergonomic Factors on Employee Productivity in Apparel Industry of Gampaha District. To achieve that objective, Chi-Square Test, Correlation Analysis \& the Regression Analysis has been used by the researcher. According to the ChiSquare test, all the independent factors have an Impact of Physical Ergonomic Factors on Employee Productivity in Apparel Industry of Gampaha District. Under Correlation Analysis, only the Environmental Factors are strong positively correlated while others correlated weak positively at $05.00 \%$ level of significance.

As per the results in regression analysis, all the Independent factors have significant impact on Employee Productivity in Apparel Industry of Gampaha District. And the
Environmental Factors have the highest significant impact since it has the highest Regression Coefficient at $05.00 \%$ level of significance.

From this study, the researcher has found that, In Most of companies, employees have an appropriate, healthy working environment to perform well \& it is affecting to increase the productivity. So, it decreases resting time during working hours, reduction in human concentration, tiredness, and absence from work for being monotonous. It means, work environment should be safe and healthy along with providing human health and comfort and increasing their productivity will increase organization productivity and also will increase quality and quantity of its products and services.

Companies provide necessary equipment and tools to facilitate employees' works to be done quickly $\&$ secure materials and equipment to be done works more easily.

There are safe working equipment in the workplaces of most companies, since most of workplace injuries are occurring as a result of using unsafe working equipment. So, safe Machineries, masks, cutting tool protection \& hearing protection equipment are used.

In Most Companies in Apparel Industry of Gampaha District, Workplace interior design elements are integrated successfully \& workplace machines design is convenient for the job performance \& workplace is designed to minimize motions. 


\section{CONCLUSION}

The major purpose of this study is to find out about the Impact of Physical Ergonomic Factors on Employee Productivity in Apparel Industry of Gampaha District. The Employee Productivity can be improved through addressing to the specific challenges as follows.

The findings of the research are confined with Niemela et al. (2002) as the selected variables may have a positive impact on employee productivity. As per the present study, the internal environment positively impact on employee productivity and the result were similar to the study conducted by Ismail et al. (2010).

Also, the study found that the working equipment may also have a impact on the employee productivity and the finding of Tamessek (2009); Ajala (2012)' Roelofsen (2002) also confirm the results of this study. Also, this research shows there is a positive relationship between workplace design and the employee productivity and the findings of Hameed and Amjad (2009) confined the results were similar to the present study.

When Employees must work in an inappropriate, unhealthy working environment, it will negatively effect on human performances. It means it will increase resting time during working hours, reduction in human concentration, tiredness, and absence from work for being monotonous. So, Companies have to pay more attention about the Temperature \& Lighting \& it should be kept at the level which helps to maintain the normal level of performance positively \& as it supports to the productivity and morale. It means, work environment should be safe and healthy along with providing human health and comfort and increasing their productivity will increase organization productivity and also will increase quality and quantity of its products and services.

Employees should use safe working equipment's in the workplace, since most of workplace injuries are occurring as a result of using unsafe working equipment. So, safe Machineries, masks, cutting tool protection \& hearing protection equipment can be used.

Organizing workplace environment and design properly is also a major thing which is directly affecting to the Employee Productivity. Therefore, should provide staff with adjustable desks, options for lighting and temperature control, and variety work rooms to increase job satisfaction and it will affect to increase the Employee Productivity. It's necessary to use well-designed workplace, since it is more convenient for employees' job performance $\&$ it will also reduce the motion of employees.

So, the present resect fills the empirical gap by finding the solutions for managing physical ergonomics in organizations towards achieving the productivity.

\section{REFERENCES}

Ajala, E.M. (2012). The influence of workplace environment on workers' welfare, performance and productivity. 
Brill, M., Marguilis, S.T., Konar, E. and BOSTI (1985), Using Office Design to IncreaseProductivity, Vol. 1\&2, Workplace Design and Productivity Inc., Buffalo, NY.

Britain, G. (2014). Ergonomics and human factors at work: a brief guide. UK: Health and Safety Executive

Carnevale, D.G., (1992), Physical Settings of Work. Public Productivity and Management Review, 15, 4, 423-436

Clements-Croome, D.J., (1997). Specifying Indoor Climate, in book Naturally Ventilated Buildings

Dorgan, C.E. (1994) productivity Link to the Indoor Environment Estimated Relative to ASHRAE 62-1989

Govindaraju, M., Pennathur, A. and Mital, A., 2001. Quality improvement in manufacturing through human performance enhancement. Integrated Manufacturing Systems, 12(5), pp.360-367.

Gujarati, D.N. and Porter, D.C. (2009) Basic Econometrics. 5th Edition, McGraw Hill Inc., New York.

Hameed, A., \& Amjad, S. (2009). Impact of office design on employee's productivity: a case study of banking organizations of abbottabad, Pakistan.

Huang, Y.H., Robertson, M.M. and Chang, K.I. (2004) The Role of Environmental Control on
Environmental Satisfaction, Communication and Psychological Stress: Effects of Office Ergonomics Training. Environment and Behavior, 36, 617-637.

Krejcie, R.V. and Morgan, D.W., 1970. Determining sample size for research activities. Educational and psychological measurement, 30(3), pp.607-610.

McCoy, J.M., \& Evans, G. (2005). Physical work environment. In J. Barling, E.K. Kelloway, \& M. Frone (Eds), Handbook of work stress (pp. 219-245). Thousand Oaks, CA: Sage Publications.

Niemelä, J., Kotze, D.J., Venn, S. et al. Carabid beetle assemblages (Coleoptera, Carabidae) across urban-rural gradients: an international comparison. Landscape Ecol 17, 387-401 (2002)

Roelofsen, P. (2002) The Impact of Office Environments on Employee Performance: The Design of the Workplace as a Strategy for Productivity Enhancement. Journal of Facilities Management, 1, 247264.

https://doi.org/10.1108/14725960 310807944

Temessek, (2009) Expanding the Psychosocial Work Environment: Workplace Norms and WorkFamily Conflict as Correlates of Stress and Health 3(1) $71-88$ 
Vischer, J., 1989. Environmental quality in offices. John Wiley \& Sons Inc. 